\title{
Oxidative stability of Opuntia ficus-indica seeds oil blending with Moringa oleifera seeds oil ${ }^{\text {is }}$
}

\author{
Mohamed Abdelbaset Salama ${ }^{1, *}$, Said El Harkaoui ${ }^{2}$, Issmail Nounah ${ }^{2}$, Hazem Sakr ${ }^{1}$, Mohamed Abdin ${ }^{1,3}$, \\ Mostafa Owon ${ }^{4}$, Mohamed Osman ${ }^{4}$, Awatif Ibrahim ${ }^{1}$, Zoubida Charrouf ${ }^{2}$ and Bertrand Matthäus ${ }^{5}$ \\ ${ }^{1}$ Food Technology Research Institute, Agriculture Research Center, Giza 12611, Egypt \\ ${ }^{2}$ Laboratoire de chimie des plantes et de synthèse organique et bioorganique, Faculté des sciences, Université Mohammed V, Rabat, \\ Morocco \\ ${ }^{3}$ College of Food Science and Technology, Nanjing Agricultural University, Nanjing, China \\ ${ }^{4}$ Food Technology Department, Faculty of Agriculture, Kafrelsheikh University, Kafrelsheikh 33511, Egypt \\ ${ }^{5}$ Max Rubner-Institut (MRI), Department of Safety and Quality of Cereals, Working Group for Lipid Research, Detmold 32756, \\ Germany
}

Received 30 June 2020 - Accepted 2 September 2020

\begin{abstract}
Enhancement of the oxidative stability of cactus seeds oil by blending with moringa seeds oil was investigated during storage period for four weeks at $50{ }^{\circ} \mathrm{C}$. Blends $(25,50$ and $75 \%)$ of moringa seeds oil with cactus seeds oil were prepared. Fatty acids composition, induction period, peroxide value, specific extinction coefficients (K232 and K270) and tocopherols were studied. Blending moringa seeds oil with cactus seeds oil at $25: 75 \%$ increases the induction period to $4.06 \mathrm{~h}$ while it was $3.16 \mathrm{~h}$ in $100 \%$ cactus seeds oil. Peroxide values decreased due to increase moringa seeds oil amount in blends. Also, adding moringa seeds oil to cactus seeds oil caused a decrease in K232 and K270 values during the storage period in comparison with $100 \%$ cactus seeds oil. $\alpha$-tocopherol values decreased during storage for all oil blends, while the content of $\gamma$-tocopherol in all samples (except moringa seeds oil) increased during storage period reaching the highest level after the third week then it started to decrease. Therefore, the obtained results provided a potential approach to utilize moringa oil to increase the oxidative stability of edible oils.
\end{abstract}

Keywords: oxidative stability / Opuntia ficus-indica seeds oil / Moringa oleifera seeds oil / blending oils

Résumé - Stabilité oxydative de l'huile de graines d'Opuntia ficus-indica en mélange avec de l'huile de graines de Moringa oleifera. L'amélioration de la stabilité oxydative de l'huile de graines de cactus (Opuntia ficus-indica) par mélange avec de l'huile de graines de moringa (Moringa oleifera), a été étudiée sur une période de stockage de quatre semaines à $50^{\circ} \mathrm{C}$. Des mélanges $(25,50$ et $75 \%)$ d'huile de graines de moringa et d'huile de graines de cactus ont été préparés, et la composition en acides gras, la période d'induction, l'indice de peroxyde, les coefficients d'extinction spécifiques (K232 et K270) et les teneurs en tocophérols ont été suivis au cours du stockage. Le mélange à $75 \%$ d'huile de graines de moringa a vu sa période d'induction augmenter à $4,06 \mathrm{~h}$, contre $3,16 \mathrm{~h}$ pour l'huile de graines de cactus à $100 \%$ (contrôle). L'augmentation du taux d'huile de graines de moringa dans les mélanges s'est traduite par une diminution de l'indice de peroxyde et des valeurs K232 et K270. La teneur en $\alpha$-tocophérol a également diminué au cours du temps dans tous les mélanges, alors que la teneur en $\gamma$-tocophérol a augmenté (sauf pour l'huile de graines de moringa) pour atteindre un maximun après la troisième semaine, et diminuer ensuite. En conclusion, les résultats obtenus ont montré que l'ajout d'huile de moringa à des huiles comestibles constituait une approche potentielle pour améliorer leur stabilité oxidative.

Mots clés : stabilité oxydative / huile de graines d'Opuntia ficus-indica / huile de graines de Moringa oleifera / mélanges d'huiles

\footnotetext{
Contribution to the Topical Issue "Minor oils from atypical plant

sources / Huiles mineures de sources végétales atypiques"

*Correspondence: mohamedabdelbasetsalama@gmail.com
} 


\section{Introduction}

Oxidative reactions effect the shelf life of processed foods and the fresh one. The main problem in deterioration edible oil is lipid oxidation which has bad effect on color, texture and aroma (Bodoira et al., 2017). In addition, many harmful substances may be formed by further oxidation (Shahidi and Zhong, 2010). Also, irreversible damages occur when a reaction take place between radical oxygen species and with biological molecules like proteins or lipids (Cabiscol et al., 2000). Preventing oil oxidation, causes an enrichment of the functional compounds which are useful for human health (Anwar et al., 2007; Frankel and Huang, 1997). Mixing different oils helps in increasing the level of natural antioxidants in the mixtures and increase quality for the oils. As well, it is an economical method to enhance physicochemical characteristics of these oils (Chu and Kung, 1997; Chu and Kung, 1998), and nowadays many countries use this method to improve edible oils (Ramadan et al., 2008). Diets which have high content of oleic acid are in a relation with lowing the bad cholesterol in blood and this may reduce coronary heart diseases (Nestel et al., 1994). Furthermore, it can help in treatment diabetes and cancer (Poudyal et al., 2012). Vegetable oils which have a high amounts of oleic oil are more favorable from a nutritional point of view because its resistance to oxidation than others contain polyunsaturated fatty acids which have poorer oxidative stability and shorter shelf-life (Bordon et al., 2019). Therefore, it is necessary to look for economical and practical methods to increase the oxidative stability and the shelf life of the vegetable oils. One of these methods is blending two or more oils which have different properties to produce new desirable products. Many advantages can be obtained by mixing vegetable oils such as adjusting fatty acid profiles and the amounts of bioactive compounds and natural antioxidants in the new blends. All of these advantages give the new products better quality, enhance oxidative stability and increase the shelf life of the produced blends (Hashempour-Baltork et al., 2016). For example, studies report the blending of some common oils like sunflower oil with canola or palm oil (Farag et al., 2010) and the combination of hydrogenated soybean oil with soybean oil, or high-oleic sunflower oil with corn oil (Naghshineh et al., 2010). Other researches have examined the effect of blending untraditional oils with common one like adding walnut to virgin olive oils (Torres et al., 2011), among others.

Cactus plant (Opuntia ficus-indica) of the Cactaceae family, grows native in Mexico and has been used since many of years as source of food. Genus Opuntia contains about 1500 species of cactus which are widespread in Africa, Mediterranean countries, Northern Mexico, Southwestern United States, and other areas (Matthäus and Özcan, 2011). Taoufik et al. (2015) reported that oil content of the seeds from many regions in Morocco ranged between 5.4\% and 9.9\%. It contains high content of unsaturated fatty acids, in which linoleic acid is the main fatty acid $(58.79 \%$ ) (Ghazi et al., 2013). Saturated fatty acids are occurring at lower percentages and comprise palmitic and stearic acids (Ramadan and Mörsel, 2003; Gharby et al., 2015; Mouden et al., 2016). About the pharmacological activity, the oil from cactus seed showed relevant antioxidant and antimicrobial activity (RamírezMoreno et al., 2017), $\alpha$-glucosidase inhibitory activity, cytotoxicity against human tumor cell lines also anti-inflammatory and analgesic activities (Chahdoura et al., 2017).

Moringa oleifera which belongs to family Moringaceae is an effective remedy for malnutrition. It is the most utilized and famous species in this family. Its original homeland is India and then spread to many countries (Morton, 1991; Mughal et al., 1999). As regards moringa seeds oil, it is a good source of oil and oleic acid is the major fatty acid (Salama et al., 2020). The oxidative stability of moringa seeds oil depends on its fatty acid composition (high amount of oleic acids and low amount of polyunsaturated fatty acids) beside its tocopherol content (antioxidant substances) (Al-Juhaimi et al., 2017; Salama et al., 2020). Also, these types of oil (oleic type) are desirable in nutrition due to its effect on coronary heart disease (Abdulkarim et al., 2007). Moringa oil is stable during frying due to its high content of oleic acid which produce low content of conjugated dienes and trienes in comparison to vegetable oils rich in ployunsturated fatty acid.

Therefore, the aim of this research was using Moringa oleifera seeds oil to enhancement the oxidative stability of Opuntia ficus-indica seeds oil. To our knowledge, this is the first work to study the effect of blending Moringa oleifera to Opuntia ficus-indica to increase its oxidative stability.

\section{Materials and methods}

\subsection{Materials}

Moringa oleifera seeds were collected from Crop Research Institute, Agricultural Research Center, Sakha, Kafrelsheikh City, Egypt at summer 2017. Cold press cactus (Opuntia ficusindica) seeds oil were obtained from Tiznit City, Morocco at summer 2017.

\subsection{Reagents}

Petroleum ether (40-60), heptane and tert-butyl methyl and cyclohexane for spectroscopy were from Merck (Darmstadt, Germany). Tocopherols standard compounds were procured from Merck (Darmstadt, Germany). Fatty acid methyl esters standard was obtained from Restek (Bad Homburg, Germany).

\subsection{Sample preparation}

Moringa seeds were sun-dried to dryness, then the seeds were ground using mill (IKA, model A11 BS000, Germany) and stored at $4{ }^{\circ} \mathrm{C}$ until usage.

\subsection{Extraction of oil}

To determine the oil amount, DGF-B-I-5 (2013) method was followed. In brief, the crushed moringa seeds $(5 \mathrm{~g})$ were extracted in a Twisselmann apparatus using $75 \mathrm{~mL}$ petroleum ether for $6 \mathrm{~h}$. Rotary evaporator (model RV 10C S93, IKAWerke GmbH \& Co. KG, Stauffen, Germany) at $40^{\circ} \mathrm{C}$ and 25 Torr was used to eliminate the solvent. The residual solvent was removed by a stream of nitrogen. 


\subsection{Effect of blending moringa seeds oil (MSO) on the stability of cactus seeds oil (CSO)}

The oils blends were formulated by blending MSO with CSO at ratios of 100:0, 75:25, 50:50, 25:75 and 0:100\%, respectively. The oils were mixed to obtain uniform blends. MSO, CSO and oil blends were put in a dark glass bottles ( $50 \mathrm{~mL}$ each). The bottles were filled completely with bure and blends oils and tightly closed. Temperature is one of the most important factors that affect lipid oxidation. So, $50{ }^{\circ} \mathrm{C}$ for up to one month was used to accelerate the oxidation reaction in a forced draft air oven. Immediately after each week, oil samples were withdrawn for triplicate analyses. The oxidation state evolution was measured by several parameters, tocopherols content, peroxide value, specific extinction coefficients and induction period.

\subsection{Fatty acids determination}

To determine fatty acids DGF-C-VI 10 (2013) and DGF-C-VI 11d (2013) were used. One drop, approximately, from the oil sample was dissolved in n-heptane $(1 \mathrm{~mL})$. After that, sodium methylate (50 $\mu \mathrm{g}$ ) (Merck, Darmstadt, Germany) was added to the tube and for $60 \mathrm{~s}$ the tube was agitated at room temperature. Centrifuge was used $(3000 \times \mathrm{g}$ for $5 \mathrm{~min})$ after adding $100 \mu \mathrm{L}$ of water to the tubes and carefully the lower aqueous phase was removed. HCL (1 mol with methyl orange; Merck, Darmstadt, Germany) $(50 \mu \mathrm{L})$ was used and the lower phase was eliminated after shortly mixing to the solution. Adding sodium hydrogen sulphate $(20 \mathrm{mg})$ (monohydrate, extra pure; Merck, Darmstadt, Germany) to the tube and at $3000 \times \mathrm{g}$ for $5 \mathrm{~min}$ the sample was centrifuged. The top phase (n-heptane) was taken to a vial and injected in GC (HP5890, Agilent Technologies Sales \& Services GmbH \& Co. KG, Waldbronn, Germany) with CP-Sil 88 a capillary column, (ID $0.25 \mathrm{~mm}, 100 \mathrm{~m}$ long, $0.2 \mu \mathrm{m}$ film thickness). The temperature program was prepared as follows: From $155^{\circ} \mathrm{C}$; reached to $220^{\circ} \mathrm{C}\left(1.5^{\circ} \mathrm{C} / \mathrm{min}\right)$, injector $250{ }^{\circ} \mathrm{C}$, $10 \mathrm{~min}$ isotherm; detector $250^{\circ} \mathrm{C}$; hydrogen as carrier gas $36 \mathrm{~cm} / \mathrm{s}$; split ratio 1:50; hydrogen as detector gas $30 \mathrm{~mL} / \mathrm{min}$; $300 \mathrm{~mL} / \mathrm{min}$ air and $30 \mathrm{~mL} / \mathrm{min}$ nitrogen; manual injection volume less than $1 \mu \mathrm{L}$. The peak areas were computed by the integration software, and percentages of fatty acid methyl esters (FAME) were obtained as weight percent by direct internal normalization.

\subsection{Tocopherols determination}

For identification and determination of tocopherols, DGFF-II 4a (2013) was used. $150 \mathrm{mg}$ of oil were dissolved in n-heptane $(1 \mathrm{~mL})$ followed by two stages of filtration the first one syringe filter $1.0 \mu \mathrm{m}$ and the second $0.45 \mu \mathrm{m}$. After filtration the sample was directly injected to the HPLC. The HPLC analysis was conducted using a Merck-Hitachi lowpressure gradient system, fitted with pump (L-6000), a MerckHitachi F-1000 fluorescence spectrophotometer, and a ChemStation integration system. The samples $(20 \mu \mathrm{L})$ were injected by auto sampler (Merck 655-A40) onto a Diol phase HPLC column $25 \mathrm{~cm} \times 4.6 \mathrm{~mm}$ ID with $1.3 \mathrm{~mL} / \mathrm{min}$ as a flow rate of n-heptane and tert-butyl methyl ether were used as a mobile phase.

\subsection{Determination of peroxide value}

By definition peroxide value (PV) is a measure of total peroxides of the oil (meq. $\mathrm{O}_{2} \mathrm{~kg}^{-1}$ oil). Acetic acid-isooctane mixture $(60: 40 \mathrm{v} / \mathrm{v})$ was used to dissolve $5 \mathrm{~g}$ from the oil sample. To this solution, $0.5 \mathrm{~mL}$ of saturated potassium iodide (KI) was added and mixed for 1 minute. Boiled Millipore water $(100 \mathrm{~mL})$ was used and the titration $(\mathrm{pH}$ metric titration) was done until the first equivalence point with alcoholic $(\mathrm{KOH})=0.1 \mathrm{~mol} / \mathrm{L}$. The titration was done automatically using METHROM Titrando 888 controlled by a software (Tiamo), facilitating the calculation of peroxide value as $\mathrm{mEq}$ of active oxygen $/ \mathrm{kg}$ oil.

\subsection{Specific extinction coefficients (K232 and K270)}

The absorbance at $232 \mathrm{~nm}$ or $270 \mathrm{~nm}$ gives a sign about the oxidation products. $250 \mathrm{mg}$ of oil were weighed into a $25 \mathrm{~mL}$ volumetric flask and diluted to $25 \mathrm{~mL}$ with cyclohexane (spectrophotometric grade).

The sample was homogenized using vortex for $30 \mathrm{~s}$ and then resulting solution was placed into a quartz cuvette. Absorbance was measured at 232 and $270 \mathrm{~nm}$ in a double beam spectrophotometer using the pure cyclohexane as a blank. The specific extinctions were calculated as follows:

$$
K \lambda=\frac{E \lambda}{C \times S}
$$

where:

$-K \lambda$ : specific extinction at wavelength $\lambda$;

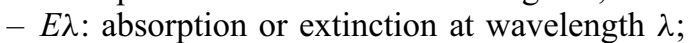

$-C$ : the solution concentration in $\mathrm{g} / 100 \mathrm{~mL}$;

$-S$ : quartz cell length $(\mathrm{cm})$.

\subsection{Rancimat method}

Induction time is a test designed to measure the relative stability of an oil sample. To measure the induction time Metrohm 743 Rancimat was used. Oil (3.6 g) was weighed and put in a heating block at $110^{\circ} \mathrm{C}$ or $120^{\circ} \mathrm{C}$. Air was forced through the sample at $20 \mathrm{~L} /$ hour. Volatile components which develop as a result of oxidation are captured in water and a conductivity metre was used in measuring. As the oil oxidized, the changes in the conductivity were recorded by the Rancimat. The point of inflection on the curve recorded when the oil had lost the ability to resist oxidation was reported as induction time in hours.

\subsection{Statistical analysis}

The data were statistically analyzed by software of SPSS (Version 16.0, SPSS Inc., Chicago, IL) to test the variance by one-way analysis of variance (ANOVA) method (Steel and Torrie, 1980). 
M.A. Salama et al.: OCL 2020, 27, 53

Table 1. Fatty acids composition (\% of total FA) of moringa (Moringa oleifera) and cactus (Opuntia ficus-indica) seeds oils and blends.

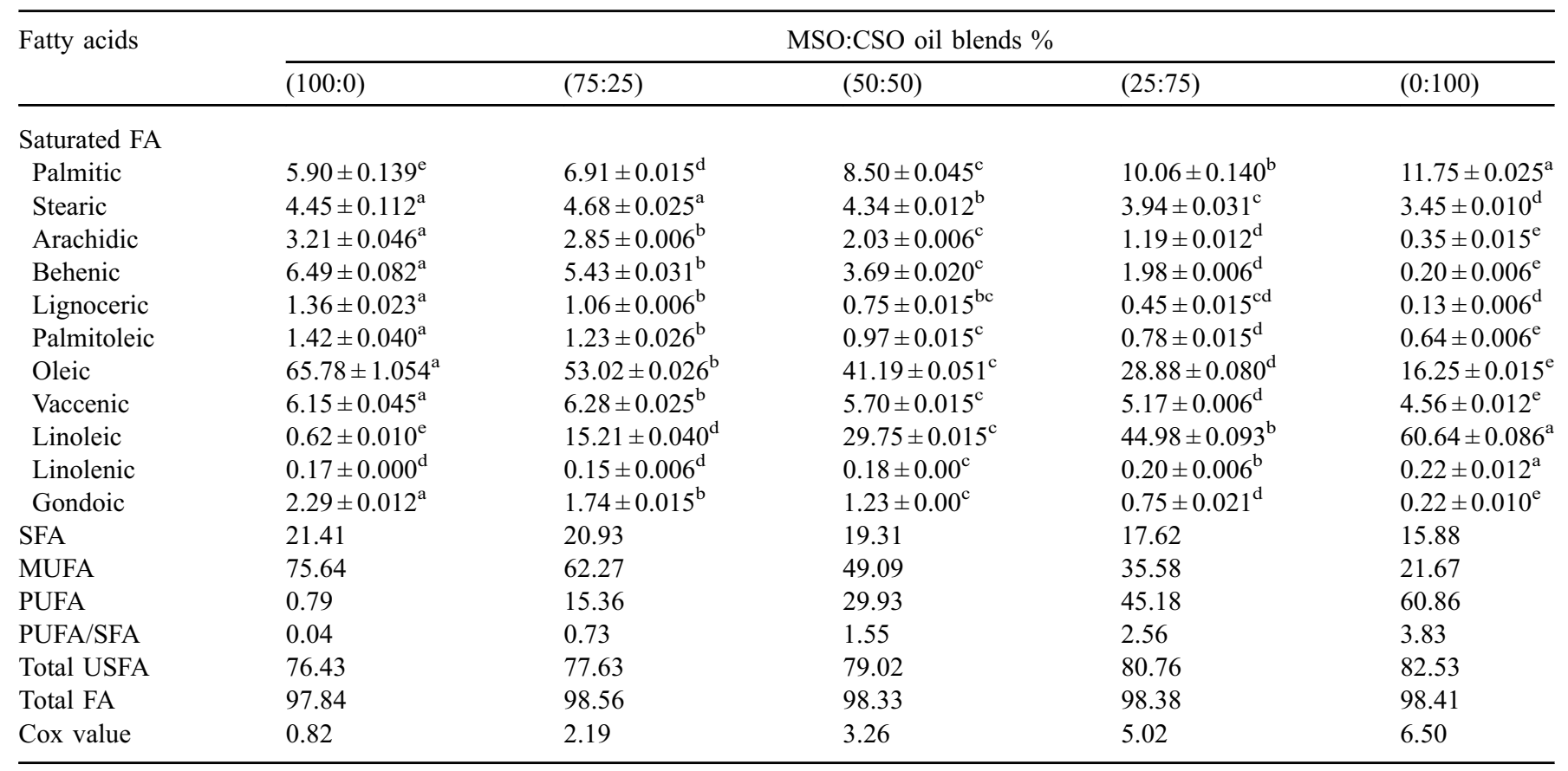

MSO: Moringa (Moringa oleifera) seeds oil; CSO: cactus (Opuntia ficus-indica) seeds oil; values are means \pm SD; means having the different case letter(s) within a row are significantly different at $P \leq 0.05$.

\section{Results and discussion}

\subsection{The change in fatty acids composition}

Table 1 shows the fatty acids composition of pure oils (MSO and $\mathrm{SCO}$ ) and their blends. Oleic, linoleic, behenic acids were the major fatty acids changed in blends. MSO contained high amount of oleic acid reached about $65.78 \%$. While, the major fatty acid in CSO was linoleic acid (60.64\%). This high value of linoleic acid may be the reason which make CSO more susceptible to oxidative rancidity. Data reveals that MSO and CSO contained SFA, MUFA, and PUFA (21.41 and 15.88\%), (75.64 and $21.67 \%$ ) and ( 0.79 and $60.86 \%)$, respectively. CSO had greater cox value than MSO reached 6.50 and 0.82 , respectively and adding MSO at 25, 50 and $75 \%$ caused a gradual decreased reached 5.02, 3.26 and 2.19. On the other hand, PUFA/SFA was higher in SCO (3.83) than MSO (0.04). It is known that cox value and the ratio of PUFA/SFA consider as a parameters of tendency of oils to undergo oxidation (Fatemi and Hammond, 1980; Mendez et al., 1996).

Blending MSO at a ratio of $75 \%$ caused an increase in oleic acid in cactus seeds oil from $16.25 \%$ to $53.02 \%$, while linoleic acid decreased from $60.64 \%$ to $15.21 \%$. An increasing in palmitic and oleic acids had occurred as a result of blending $\mathrm{MSO}$ with CSO at different ratios, which has a good effect on oxidative stability as mentioned by Abdel-Razek et al. (2011). Many studies mentioned near effects of blending oils. Anwar et al. (2007) and Li et al. (2014) who reported that adding MSO to soybean and sunflower oils caused a decrease in linoleic acid and an increase in oleic acid in oil blends. Also, Guiotto et al. (2014) found that blending of chia oils with sunflower kernel oil caused modifications in the blends' fatty acid profile.
Table 2. Induction period (IP) of Moringa oleifera and cactus (Opuntia ficus-indica) seeds oils and blends.

\begin{tabular}{lcc}
\hline Samples & Blends ratio $\%$ & Induction period (hrs) \\
\hline MSO:CSO & $100: 0$ & $10.58 \pm 0.326^{\mathrm{a}}$ \\
MSO:CSO & $75: 25$ & $8.95 \pm 0.152^{\mathrm{b}}$ \\
MSO:CSO & $50: 50$ & $5.79 \pm 0.118^{\mathrm{c}}$ \\
MSO:CSO & $25: 75$ & $4.06 \pm 0.087^{\mathrm{d}}$ \\
MSO:CSO & $0: 100$ & $3.16 \pm 0.040^{\mathrm{e}}$ \\
\hline
\end{tabular}

MSO: Moringa (Moringa oleifera) seeds oil; CSO: cactus (Opuntia ficus-indica) seeds oil; values are means $\pm \mathrm{SD}$; Means having the different case letter(s) within a row are significantly different at $P \leq 0.05$.

\subsection{The change in induction periods (IP)}

The investigated samples sensitivity to oxidation was measured by the rancimat test. The end point of this test can be determined by induction period (IP) to the inflection point in the oxidation curve (Mendez et al., 1997). The length of IP is considered a relative measure of the oils stability. IP results of MSO, CSO and blends were displayed in Table 2.

It was found that CSO was extremely susceptible to oxidation (3.16), while MSO had the highest IP (10.58). Blending with MSO improved clearly the oxidative stability. IP of oil blends significantly increased as a result of adding MSO to CSO. Mixing $25 \%$ of MSO to CSO increased its the thermal stability reached about 4.06 in comparison with pure CSO (3.16). Abdel-Razek et al. (2011) reported that, mixing olive oil (IP 31.1) with soybean oil (IP 9.63) and sunflower oil 
Table 3. Determination of peroxide value (meq. $\mathrm{O}_{2} / \mathrm{kg}$ oil) of moringa (Moringa oleifera) and cactus (Opuntia ficus-indica) seeds oils and blends during storage at $50^{\circ} \mathrm{C}$ for four weeks.

\begin{tabular}{|c|c|c|c|c|c|c|}
\hline Samples & Blending ratio $(\%)$ & \multicolumn{5}{|c|}{ Storage time (week) at $50^{\circ} \mathrm{C}$} \\
\hline MSO:CSO & 100:0 & $0.43 \pm 0.026^{\mathrm{e}}$ & $7.70 \pm 0.223^{\mathrm{d}}$ & $8.95 \pm 0.115^{\mathrm{d}}$ & $9.02 \pm 0.080^{\mathrm{e}}$ & $11.05 \pm 0.026^{\mathrm{e}}$ \\
\hline MSO:CSO & $75: 25$ & $0.78 \pm 0.070^{\mathrm{d}}$ & $8.30 \pm 0.157^{\mathrm{c}}$ & $10.67 \pm 0.231^{\mathrm{d}}$ & $12.60 \pm 0.333^{\mathrm{b}}$ & $12.94 \pm 0.217^{\mathrm{d}}$ \\
\hline MSO:CSO & $50: 50$ & $1.64 \pm 0.036^{\mathrm{c}}$ & $8.90 \pm 0.040^{\mathrm{b}}$ & $11.89 \pm 0.290^{\mathrm{c}}$ & $17.35 \pm 0.072^{\mathrm{c}}$ & $20.85 \pm 0.190^{\mathrm{c}}$ \\
\hline MSO:CSO & $25: 75$ & $1.86 \pm 0.045^{\mathrm{b}}$ & $8.68 \pm 0.290^{\mathrm{bc}}$ & $12.94 \pm 0.026^{\mathrm{b}}$ & $19.67 \pm 0.327^{\mathrm{b}}$ & $25.22 \pm 0.195^{\mathrm{b}}$ \\
\hline
\end{tabular}

MSO: Moringa (Moringa oleifera) seeds oil; CSO: cactus (Opuntia ficus-indica) seeds oil; values are means \pm SD; means having the different case letter(s) within a column are significantly different at $P \leq 0.05$.

Table 4. Specific extinction coefficients (K232) of moringa (Moringa oleifera) and cactus (Opuntia ficus-indica) seeds oils and blends during storage at $50{ }^{\circ} \mathrm{C}$ for four weeks.

\begin{tabular}{|c|c|c|c|c|c|c|}
\hline \multirow[t]{2}{*}{ Samples } & \multirow[t]{2}{*}{ Blends ratio $(\%)$} & \multicolumn{5}{|c|}{ Storage time (week) at $50^{\circ} \mathrm{C}$} \\
\hline & & 0 & 1 & 2 & 3 & 4 \\
\hline MSO:CSO & $100: 0$ & $2.61 \pm 0.006^{\mathrm{e}}$ & $2.67 \pm 0.024^{\mathrm{d}}$ & $2.56 \pm 0.210^{\mathrm{e}}$ & $2.36 \pm 0.050^{\mathrm{e}}$ & $2.33 \pm 0.031^{\mathrm{e}}$ \\
\hline MSO:CSO & $50: 50$ & $2.81 \pm 0.023^{\mathrm{c}}$ & $3.16 \pm 0.171^{\mathrm{bc}}$ & $3.34 \pm 0.021^{\mathrm{c}}$ & $4.23 \pm 0.075^{\mathrm{c}}$ & $5.26 \pm 0.167^{\mathrm{c}}$ \\
\hline MSO:CSO & $25: 75$ & $3.04 \pm 0.067^{\mathrm{b}}$ & $3.46 \pm 0.242^{\mathrm{ab}}$ & $3.71 \pm 0.006^{\mathrm{b}}$ & $4.88 \pm 0.042^{\mathrm{b}}$ & $6.07 \pm 0.012^{b}$ \\
\hline
\end{tabular}

MSO: Moringa (Moringa oleifera) seeds oil; CSO: cactus (Opuntia ficus-indica) seeds oil; values are means \pm SD; means having the different case letter(s) within a row are significantly different at $P \leq 0.05$.

(IP 10.1) caused an increase in IP for new blends. Also, Guiotto et al. (2014) studied the effect of making blends between sunflower and chia oils. They found that blending sunflower oil to chia oil led to increase IP from $3.0 \mathrm{~h}$ for chia oil to $7.6 \mathrm{~h}$ for (80:20\% sunflower:chia) and to $9.2 \mathrm{~h}$ for $(90: 10 \%$ sunflower: chia). These previous results confirm that the presence of oleic acid in the oil leads to an increase in the thermal stability of pure oils and its blends.

\subsection{The change in peroxide value}

The results of blending MSO and CSO on peroxide value during accelerated oven test storage at $50{ }^{\circ} \mathrm{C}$ for four weeks were represented in Table 3. Peroxide value is considered as a parameter for the production of lipid oxidation primary products (hydroperoxides) (Ramadan and Mörsel, 2004; Mohdaly et al., 2010). The results showed that peroxide values increased as a result of increment storage time for all oil samples.

The initial value of PV of CSO was the highest one among all samples reached 2.08 meq. $\mathrm{O}_{2} \mathrm{~kg}^{-1}$ oil. Peroxide values decreased as a result of increasing MSO. Pure CSO exceeded the limit of PV (15.0 meq. $\mathrm{O}_{2} \mathrm{~kg}^{-1}$ oil) for safety consumption of oils (Codex Alimentarius, 2001) after the end of the second week. On the other hand, pure MSO did not reach this limit until the end of the storage period. This may be due to the high content of oleic acid and low amount of linoleic and linolenic acids in MSO and on the contrary in CSO. Adding 25 and $50 \%$ from MSO to SCO delay reaching the limit of PV (15.0 meq. $\mathrm{O}_{2} \mathrm{~kg}^{-1}$ oil $)$ for the end of third week in comparison with pure CSO which reached this limit at the end of second week. While, adding 75\% from MSO showed similar to pure MSO. By the end of storage period, PV reached $39.53,25.22,20.85,12.94$ and 11.05 meq. $\mathrm{O}_{2} \mathrm{~kg}^{-1}$ oil for MSO:CSO (0:100\%), MSO:CSO (25:75\%), MSO:CSO (50:50\%), MSO:CSO (75:25\%) and MSO:CSO (100:0\%), respectively.

The obtained results were in the same trend of those reported by Anwar et al. (2007). They found that adding moringa oil $(20 \%)$ to soybean oil decreased peroxide values. The same effect was observed by adding olive oil (high in oleic acid) to sunflower (high in linoleic acid) and soybean (high in linoleic acid) which caused slowdown in the increase in PV (Abdel-Razek et al., 2011). In general, increasing the amount of linoleic acid and/or decreasing the level of oleic acid caused a decrease in the oxidative stability of oil blends (Naghshineh et al., 2010).

\subsection{The change in specific extinction coefficients (K232 and K270)}

The formation of hydroperoxides has a relationship with double bonds conjugated in polyunsaturated fatty acids, which measured by absorption using the UV spectrum (Ramadan and Mörsel, 2004). For evaluation the stability of fan and oil, measuring conjugated diene (CD) and triene (CT) are good parameters. The more CD and CT, the less oxidative stability (Mohdaly et al., 2010). These absorptions are expressed as specific extinctions $\mathrm{E}$ (the extinction of $1 \%$ solution of the oil in the specific solvent in a $10 \mathrm{~mm}$ cell) conventionally indicate by $\mathrm{K}$ (also referred to as extinction coefficients). 
Table 5. Specific extinction coefficients (K270) of moringa (Moringa oleifera) and cactus (Opuntia ficus-indica) seeds oils and blends during storage at $50^{\circ} \mathrm{C}$ for four weeks.

\begin{tabular}{|c|c|c|c|c|c|c|}
\hline Sample & Blend ratio $(\%)$ & \multicolumn{5}{|c|}{ Storage time (week) at $50^{\circ} \mathrm{C}$} \\
\hline MSO:CSO & $100: 0$ & $0.20 \pm 0.006^{\mathrm{c}}$ & $0.21 \pm 0.012^{\mathrm{d}}$ & $0.18 \pm 0.00^{\mathrm{d}}$ & $0.20 \pm 0.010^{\mathrm{d}}$ & $0.20 \pm 0.010^{\mathrm{d}}$ \\
\hline MSO:CSO & $75: 25$ & $0.17 \pm 0.000^{\mathrm{d}}$ & $0.18 \pm 0.00^{\mathrm{e}}$ & $0.18 \pm 0.006^{\mathrm{d}}$ & $0.18 \pm 0.006^{\mathrm{e}}$ & $0.18 \pm 0.00^{\mathrm{e}}$ \\
\hline MSO:CSO & $50: 50$ & $0.22 \pm 0.010^{\mathrm{b}}$ & $0.23 \pm 0.012^{\mathrm{c}}$ & $0.24 \pm 0.012^{\mathrm{c}}$ & $0.25 \pm 0.010^{\mathrm{c}}$ & $0.24 \pm 0.006^{\mathrm{c}}$ \\
\hline MSO:CSO & $25: 75$ & $0.23 \pm 0.010^{\mathrm{b}}$ & $0.25 \pm 0.00^{\mathrm{b}}$ & $0.30 \pm 0.006^{\mathrm{b}}$ & $0.30 \pm 0.015^{\mathrm{b}}$ & $0.30 \pm 0.00^{\mathrm{b}}$ \\
\hline
\end{tabular}

MSO: Moringa (Moringa oleifera) seeds oil; CSO: cactus (Opuntia ficus-indica) seeds oil; values are means \pm SD; means having the different case letter(s) within a row are significantly different at $P \leq 0.05$.

Table 6. $\alpha$-tocopherol content ( $\mathrm{mg} / 100 \mathrm{~g}$ ) of moringa (Moringa oleifera) and cactus (Opuntia ficus-indica) seeds oils and blends during storage at $50{ }^{\circ} \mathrm{C}$ for four weeks.

\begin{tabular}{|c|c|c|c|c|c|c|}
\hline Sample & Blending ratio $(\%)$ & \multicolumn{5}{|c|}{ Storage time (week) at $50^{\circ} \mathrm{C}$} \\
\hline MSO:CSO & 100:0 & $20.92 \pm 0.710^{\mathrm{a}}$ & $11.02 \pm 0.387^{\mathrm{a}}$ & $11.18 \pm 0.897^{\mathrm{a}}$ & $13.98 \pm 0.608^{\mathrm{a}}$ & $11.28 \pm 0.021^{\mathrm{a}}$ \\
\hline MSO:CSO & $50: 50$ & $14.55 \pm 0.435^{\mathrm{c}}$ & $6.83 \pm 0.081^{\mathrm{c}}$ & $6.72 \pm 0.087^{\mathrm{c}}$ & $9.71 \pm 1.163^{\mathrm{c}}$ & $8.42 \pm 0.195^{\mathrm{c}}$ \\
\hline MSO:CSO & $25: 75$ & $7.25 \pm 0.079^{\mathrm{d}}$ & $4.00 \pm 0.236^{\mathrm{d}}$ & $3.97 \pm 0.120^{\mathrm{d}}$ & $4.73 \pm 0.017^{\mathrm{d}}$ & $4.62 \pm 0.227^{\mathrm{d}}$ \\
\hline
\end{tabular}

MSO: Moringa (Moringa oleifera) seeds oil; CSO: cactus (Opuntia ficus-indica) seeds oil; values are means $\pm \mathrm{SD}$; means having the different case letter(s) within a column are significantly different at $P \leq 0.05$.

The conjugated diene (K232) results of MSO and CSO and blends at $50^{\circ} \mathrm{C}$ during storage for four weeks were given in Table 4. Absorption at $232 \mathrm{~nm}$ measure the primary products of oxidation. The results were in the same trend of PV results (Tab. 3). Increasing storage time caused an increase in absorption at $232 \mathrm{~nm}$ and this was due to conjugated dienes formation. MSO and CSO had initial K232 value reached 2.61 and 3.13, respectively. CSO had higher final K232 values in comparison to the others reached up to 8.98 . MSO/CSO blends have smaller values than those of pure CSO. Adding MSO to CSO caused a decrease in K232 values during storage period. Conjugated dienes and trienes high content in CSO may be due to the high level of linoleic acid which broke down to form conjugated hydroperoxides. K232 and K270 values from pure MSO were unchanged greatly throughout the storage period.

In addition, K270 refers to the absorbance of the conjugated trienes and secondary products of oxidation (Manai-Djebali et al., 2012; Bachari-Saleh et al., 2013). The results in Table 5 showed that, MSO had lower K270 than $\mathrm{CSO}$ at zero time ( 0.20 and 0.32 , respectively) and also after one month of storage ( 0.20 and 0.37 , respectively). The storage at $50{ }^{\circ} \mathrm{C}$ for four weeks led to little in the K270 values (Tab. 5). This result can be illustrated by the fact that the secondary compounds have not yet been formed and the oxidation stops at hydroperoxides formation.

These results were in the same trend of others reported by Torres et al. (2006) who mentioned that K232 values increased suddenly from day $6\left(144 \mathrm{~h}\right.$ of storage at $\left.60^{\circ} \mathrm{C}\right)$, whereas K270 values increased gradually along all the storage period of soybean and jojoba oils and their blends. Also, K232 values of sunflower, black cumin oils and their blends increased by the end of the storage period (16 days) due to the formation of conjugated diene and the values reached up to 69.22 for sunflower oil, 46.70-56.72 for blends and 17.71 for black cumin oil (Kiralan et al., 2017).

\subsection{The change in tocopherols}

Vitamin E contains a group of compounds which are fatsoluble with antioxidative activity (Dörmann, 2007). Tocopherols consider as good antioxidants and play role as radical scavengers (Mène-Saffrané and DellaPenna, 2010). Generally, nuts, vegetable oils and seeds are a good source of tocopherols (Dörmann, 2007). Vegetable oils tocopherols have an important function in protecting fatty acids especially polyunsaturated against oxidation and improving the oxidation stability (Kiralan et al., 2017).

$\alpha$ - and $\gamma$-tocopherols were the highest tocopherols in MSO and $\mathrm{CSO}$ and the values were within the ranges reported by others (Taoufik et al., 2015; Gharby et al., 2015; Al-Juhaimi et al., 2017; Salama et al., 2018). $\alpha$ - and $\gamma$-tocopherols in MSO and $\mathrm{CSO}$ and their blends during storage for four weeks at $50{ }^{\circ} \mathrm{C}$ were presented in Tables 6 and 7. $\alpha$-tocopherol content in MSO was considerably higher than in CSO (20.92 and $1.01 \mathrm{mg} / 100 \mathrm{~g}$, respectively), while $\gamma$-tocopherol was higher in CSO than in MSO (45.45 and $5.77 \mathrm{mg} / 100 \mathrm{~g}$, respectively) (Tables 6 and Tabs. 6 and 7). The amount of $\alpha$-tocopherol in 
Table 7. $\gamma$-tocopherol content (mg/100 g) of moringa (Moringa oleifera) and cactus (Opuntia ficus-indica) seeds oils and blends during storage at $50{ }^{\circ} \mathrm{C}$ for four weeks.

\begin{tabular}{|c|c|c|c|c|c|c|}
\hline Sample & Blending ratio $(\%)$ & \multicolumn{5}{|c|}{ Storage time (week) at $50^{\circ} \mathrm{C}$} \\
\hline MSO:CSO & $100: 0$ & $5.77 \pm 0.278^{\mathrm{a}}$ & $3.50 \pm 0.06^{\mathrm{e}}$ & $3.75 \pm 0.322^{\mathrm{e}}$ & $4.05 \pm 0.211^{\mathrm{e}}$ & $4.82 \pm 0.059^{\mathrm{d}}$ \\
\hline MSO:CSO & $75: 25$ & $16.58 \pm 0.179^{\mathrm{d}}$ & $17.28 \pm 0.237^{\mathrm{d}}$ & $20.72 \pm 3.562^{\mathrm{d}}$ & $21.77 \pm 2.423^{\mathrm{d}}$ & $19.78 \pm 0.310^{\mathrm{c}}$ \\
\hline MSO:CSO & $50: 50$ & $25.88 \pm 0.709^{c}$ & $29.98 \pm 0.358^{\mathrm{c}}$ & $29.66 \pm 0.177^{\mathrm{c}}$ & $39.69 \pm 5.523^{\mathrm{c}}$ & $34.86 \pm 0.052^{\mathrm{b}}$ \\
\hline MSO:CSO & $25: 75$ & $39.03 \pm 0.731^{\mathrm{b}}$ & $42.05 \pm 0.777^{\mathrm{b}}$ & $42.48 \pm 0.308^{\mathrm{b}}$ & $52.46 \pm 1.552^{\mathrm{b}}$ & $52.55 \pm 1.357^{\mathrm{a}}$ \\
\hline
\end{tabular}

MSO: Moringa (Moringa oleifera) seeds oil; CSO: cactus (Opuntia ficus-indica) seeds oil; values are means \pm SD; means having the different case letter(s) within a column are significantly different at $P \leq 0.05$.

MSO was higher than the amount measured in canola, corn and soybean oils (12.0, 17.3 and $7.1 \mathrm{mg} / 100 \mathrm{~g}$, respectively). Also, $\gamma$-tocopherol in CSO was higher than its amount in canola, corn, sunflower and soybean oils (12.2, 25.9, 9.2 and $27.3 \mathrm{mg} / 100 \mathrm{~g}$, respectively) (Grilo et al., 2014).

From Table 6, $\alpha$-tocopherol amount in the samples were in the following order: MSO > (MSO:CSO, 75:25) > (MSO: $\mathrm{CSO}, 50: 50)>(\mathrm{MSO}: \mathrm{CSO}, 25: 75)>\mathrm{CSO}$ during storage for four weeks at $50{ }^{\circ} \mathrm{C}$. $\alpha$-tocopherol level decreased during the first and second weeks for pure oils and their blends. After that, by the end of the third week the amount of $\alpha$-tocopherol increased in (MSO), (MSO:CSO 75:25), (MSO:CSO, 50:50) and (MSO:CSO, 25:75) reached about 13.98, 11.37, 9.71 and $4.73 \mathrm{mg} / 100 \mathrm{~g}$, respectively. Generally, the amount of $\alpha$-tocopherol decreased during storage period in comparison with zero time. These results were in harmony with those reported by Kiralan et al. (2017), Capitani et al. (2011) and Abramovic et al. (2007) in which $\alpha$-tocopherol decreased during storage period in black cumin and sunflower oils, wheat germ oil and Camelina sativa oil, respectively. After the third week and by the end of storage period $\alpha$-tocopherol started to decrease again in all samples. Only pure CSO decreased over the storage period.

Réblová (2006) reported that $\alpha$-tocopherol activity at $90^{\circ} \mathrm{C}$ was higher than its activity at $80^{\circ} \mathrm{C}$ in pork lard and decreased by increasing temperature. Also, Marinova and Yanishlieva $(1996,1998)$ and Yanishlieva and Marinova (1996) stated that the $\alpha$-tocopherol activity increases with increasing temperature in the temperature range from 20 to $100{ }^{\circ} \mathrm{C}$. The effect of temperature range from 90 to $120^{\circ} \mathrm{C}$ on the antioxidant activity of $\alpha$-tocopherol was studied by Nakatani et al. (2001). They mentioned that $\alpha$-tocopherol antioxidant activity was constant or slightly decreases with increasing temperature in the temperature range from 90 to $120^{\circ} \mathrm{C}$. In addition, Sabliov et al. (2009) studied the effect of temperature on $\alpha$-tocopherol degradation and found that $\alpha$-tocopherol heated at 40,60, and $120{ }^{\circ} \mathrm{C}$ degraded at a non-significantly different rate, with halftime values of $8.2,10.1$, and $8.2 \mathrm{~h}$, respectively. Another explanation, may be due to the stability of $\alpha$-tocopherol at high temperatures if no oxygen is present (Shin et al., 1997; Verleyen et al., 2001) and that what happened in our study in which the bottles were filled completely with bure and blends oils and tightly closed. All these previous studies may contribute to explain what had happened in our experiment in which $\alpha$-tocopherol level increased by the end of the third week and by increasing the storage period at $50^{\circ} \mathrm{C}$ for another week it started to decrease, taking into consideration that the temperature in our study was $50^{\circ} \mathrm{C}$.

As for $\gamma$-tocopherol, different effect had been observed. The amounts of $\gamma$-tocopherol in (MSO:CSO 75:25), (MSO: CSO, 50:50), (MSO:CSO, 25:75) and (MSO:CSO, 0:100) were $16.58,25.88,39.03$ and $45.45 \mathrm{mg} / 100 \mathrm{~g}$ at zero time. These amounts started to increase and reached the highest amount by the end of third week. This effect was different with the effect happened in $\alpha$-tocopherol which started to decreased after the first week. At the end of the fourth week, $\gamma$-tocopherol levels were lower than its amount in the third week. For pure MSO, $\gamma$-tocopherol decreased during the storage period. This increase may explain the decrease in oxidation products (related with K232 and K270 values) in the oil samples. Also, $\gamma$-tocopherol provides a more stable and more efficient antioxidant for food lipids than $\alpha$-tocopherol (Wanger et al., 2004) and $\alpha$-tocopherol loss its antioxidant activity higher than $\gamma$-tocopherol (Evans et al., 2002; Isnardy et al., 2003).

\section{Conclusion}

It is well known that, MSO has high natural antioxidants especially tocopherols and polyphenols, besides high level of oleic acid. All of these compounds have a role in protecting oils from oxidation. Adding 25\% from MSO to CSO caused a reduce in the production of hydroperoxides and this may decrease the production of secondary oxidation products. Blending $\mathrm{MSO}$ in different ratios with $\mathrm{CSO}$ improves the oxidative stability of CSO as approved by the results of peroxide value, K232 and K270. Adding 75, 50 and 25\% of MSO to CSO increase its shelf life in comparison with $100 \%$ SCO.

\section{Conflict of interest}

The authors declare that they have no conflicts of interest in relation to this article.

Acknowledgements. The first author is most grateful for the financial support provided by the Ministry of Higher Education and Scientific Research, Egypt, and the technical support 
provided by the members of the Working Group of Lipid Research at the Department for Safety and Quality for Cereals in Detmold, Germany of the Max-Rubner-Institut.

\section{References}

Abdel-Razek AG, El-Shami SM, El-Mallah MH, Hassanien MMM. 2011. Blending of virgin olive oil with less stable edible oils to strengthen their antioxidative potencies. Aust J Basic Appl Sci 5 (10): 312-318.

Abdulkarim SM, Long K, Lai MO, Muhammad SKS, Ghazali HM. 2007. Frying quality and stability of high-oleic Moringa oleifera seed oil in comparison with other vegetable oils. Food Chem 105: 1382-1389. Available from https://doi.org/10.1016/j.food chem.2007.05.013.

Abramovic H, Butinar B, Nikolic V. 2007. Changes occurring in phenolic content, tocopherol composition and oxidative stability of Camelina sativa oil during storage. Food Chem 104: 903-909. Available from https://doi.org/10.1016/j.food chem.2006.12.044.

Al-Juhaimi F, Ghafoor K, Babiker EE, Matthaus B, Ozcan MM. 2017. The biochemical composition of the leaves and seeds meals of moringa species as non-conventional sources of nutrients. J Food Biochem 41(1): e12322. Available from https://doi.org/10.1111/ jfbc. 12322.

Anwar F, Hussain AI, Iqbal S, Bhanger MI. 2007. Enhancement of the oxidative stability of some vegetable oils by blending with Moringa oleifera oil. Food Chem 103: 1181-1191. Available from https://doi.org/10.1016/j.foodchem.2006.10.023.

Bachari-Saleh Z, Ezzatpanah H, Aminafshar M, Safafar H. 2013. The effect of refining process on the conjugated dienes in soybean oil. J Agric Sci Technol 15: 1185-1193.

Bodoira R, Penci M, Ribotta P, Martinez M. 2017. Chia (Salvia hispanica L.) oil stability: study of the effect of natural antioxidants. LWT Food Sci Technol 75: 107-113. Available from https://doi.org/10.1016/j.lwt.2016.08.031.

Bordon MG, Meriles SP, Ribotta PD, Martinez ML. 2019. Enhancement of composition and oxidative stability of chia (Salvia hispanica L.) seed oil by blending with specialty oils. $J$ Food Sci 84(5): 1035-1044. Available from https://doi.org/ 10.1111/1750-3841.14580.

Cabiscol E, Tamarit J, Ros J. 2000. Oxidative stress in bacteria and protein damage by reactive oxygen species. Int Microbiol 3: 3-8. Available from https://doi.org/10.1093/oxfordjournals.jbchem. a021519.

Capitani M, Mateo CM, Nolasco SM. 2011. Effect of temperature and storage time of wheat germ on the oil tocopherol concentration. Braz J Chem Eng 28(2): 243-250. Available from https://doi.org/ 10.1590/S0104-66322011000200008.

Chahdoura H, Barreira JCM, Adouni K, et al. 2017. Bioactivity and chemical characterization of Opuntia macrorhiza Engelm. seed oil: potential food and pharmaceutical applications. Food Funct 8 (8): 2739-2747. Available from https://doi.org/10.1039/ C7FO00731K.

Chu YH, Kung YH. 1997. A study on oxidative stability of vegetable oil blends. Shipin Kexue 24(4): 389-397.

Chu YH, Kung YH. 1998. A study on vegetable oil blends. Food Chem 62(1): 191-195. Available from https://doi.org/10.1016/ S0308-8146(97)00200-8.

Codex Alimentarius. 2001. Fats, oils and related products, 2nd ed. Rome, Italy: FAO/WHO Food Standards Programme.

DGF, Deutsche Gesellschaft fur Fettwissenschaften e. V., Deutsche Einheitsmethoden zur Untersuchung von Fetten, Fettprodukten,
Tensiden und verwandten Stoffen, Wissenschaftliche Verlagsgesellschaft, Stuttgart (2013).

Dörmann P. 2007. Functional diversity of tocochromanols in plants. Planta 225: 269-276. Available from https://doi.org/10.1007/ s00425-006-0438-2.

Evans JC, Kodali DR, Addis PB. 2002. Optimal tocopherol concentrations to inhibit soybean oil oxidation. J Am Oil Chem Soc 79: 47-51. Available from https://doi.org/10.1007/ s11746-002-0433-6.

Farag R, El-Agamy M, Abd El Hakeem B. 2010. Effects of mixing canola and palm oils with sunflower oil on the formation of trans fatty acids during frying. Food Nutr Sci 1: 24-29. Available from https://doi.org/10.4236/fns.2010.11005.

Fatemi SH, Hammond EG. 1980. Analysis of oleate, linoleate and linolenate hydroperoxides in oxidized ester mixtures. Lipids 15 : 379-385. Available from https://doi.org/10.1007/BF02533555.

Frankel E, Huang S. 1997. Improving the oxidative stability of polyunsaturated vegetable oils by blending with high oleic sunflower oil. J Am Oil Chem Soc 71: 255-259. Available from https://doi.org/10.1007/BF02638050.

Gharby S, Harhar H, Charrouf Z, Bouzobaa Z, Boujghagh M, Zine S. 2015. Physicochemical composition and oxidative stability of Opuntia ficus indica seed oil from Morocco. Acta Hortic 1(1067): 83-88. Available from https://doi.org/10.17660/Acta Hortic.2015.1067.11.

Ghazi Z, Ramdani M, Fauconnier ML, El Mahi B, Cheikh R. 2013. Fatty acids sterols and vitamin E composition of seed oil of Opuntia ficus indica and Opuntia dillenii from Morocco. J Mater Environ Sci 4(6): 967-972.

Grilo EC, Costa PN, Gurgel CSS, Beserra AF, Almeida FN, Dimenstein R. 2014. Alpha-tocopherol and gamma-tocopherol concentration in vegetable oils. Food Sci Technol Camp 34(2): 379-385. Available from https://doi.org/10.1590/ S0101-20612014005000031.

Guiotto EN, Ixtaina VY, Nolasco SM, Tomas MC. 2014. Effect of storage conditions and antioxidants on the oxidative stability of sunflower-chia oil blends. J Am Oil Chem Soc 91: 767-776. Available from https://doi.org/10.1007/s11746-014-2410-9.

Hashempour-Baltork F, Torbati M, Azadmard-Damirchi S, Savage GP. 2016. Vegetable oil blending: a review of physicochemical, nutritional and health effects. Trends Food Sci Technol 57: 52-58. Available from https://doi.org/10.1016/j.tifs.2016.09.007.

Isnardy B, Wagner KH, Elmadfa I. 2003. Effects of $\alpha-, \gamma$ - and $\delta$ tocopherols on the autoxidation of purified rapeseed oil triacylglycerols in a system containing low oxygen. J Agric Food Chem 51: 7775-7780. Available from https://doi.org/ 10.1021/jf0348525.

Kiralan M, Ulas M, Özaydin A, et al. 2017. Blends of cold pressed black cumin oil and sunflower oil with improved stability: a study based on changes in the levels of volatiles, tocopherols, and thymoquinone during accelerated oxidation conditions. J Food Biochem 41: e12272. Available from https://doi.org/10.1111/ jfbc. 12272 .

Li Y, Ma W-J, Qi B-K, et al. 2014. Blending of soybean oil with selected vegetable oils: Impact on oxidative stability and radical scavenging activity. Asian Pac J Cancer Prev 15: 2583-2589. Available from https://doi.org/10.7314/apjcp.2014.15.6.2583.

Manai-Djebali H, Krichène D, Ouni Y, et al. 2012. Chemical profiles of five minor olive oil varieties grown in Central Tunisia. $J$ Food Compos Anal 27(2): 109-119. Available from https://doi.org/ 10.1016/j.jfca.2012.04.010.

Marinova EM, Yanishlieva NV. 1996. Antioxidative action of some flavonoids at ambient and high temperatures. Riv Ital Sos Grasse 73: $445-449$. 
Marinova EM, Yanishlieva NV. 1998. Antioxidative action of quercetin and morin in triacylglycerols of sunflower oil at ambient and high temperatures. Seifen Öle Fette Wachse 124: 1016.

Matthäus B, Özcan MM. 2011. Habitat effects on yield, fatty acid composition and tocopherol contents of prickly pear (Opuntia ficus-indica L.) seed oils. Sci Hortic 131: 95-98. Available from https://doi.org/10.1016/j.scienta.2011.09.027.

Mendez E, Sanhueza J, Speisky H, Valenzuela A. 1996. Validation of the rancimat test for the assessment of the relative stability of fish oils. J Am Oil Chem Soc 73: 1033-1037. Available from https:// doi.org/10.1007/BF02523412.

Mendez E, Sanhueza J, Speisky H, Valenzuela A. 1997. Comparison of rancimat evaluation modes to assess oxidative stability of fish oils. J Am Oil Chem Soc 74: 331-332. Available from https://doi. org/10.1007/s11746-997-0146-5.

Mène-Saffrané L, DellaPenna D. 2010. Biosynthesis, regulation and functions of tocochromanols in plants. Plant Physiol Biochem 48: 301-309. Available from https://doi.org/10.1016/j.pla phy.2009.11.004.

Mohdaly AAA, Sarhan MA, Mahmoud A, Ramadan MF, Smetanska I. 2010. Antioxidant efficacy of potato peels and sugar beet pulp extracts in vegetable oils protection. Food Chem 123: 1019-1026. Available from https://doi.org/10.1016/j.foodchem.2010.05.054.

Morton JF. 1991. The Horse radish tree, Moringa pterygosperma (Moringaceae)-A boon to arid lands. Econ Bot 45: 318-333. Available from https://doi.org/10.1007/BF02887070.

Mouden M, Boujnah M, Salmaoui S, Zantar S, Douira A. 2016. Effect of two extraction methods and harvest period and performance their statement of fatty oils of figs pear seed. Int J Pure App Biosci 4(1): $1-8$.

Mughal MH, Ali G, Srivastava PS, Iqbal M. 1999. Improvement of drumstick (Moringa pterygosperms Gaertn.) - a unique source of food and medicine through tissue culture. Hamdard Med 42: 37-42.

Naghshineh M, Ariffin A, Ghazali H, Mirhosseini H, Mohammad A. 2010. Effect of saturated/unsaturated fatty acid ratio on physicochemical properties of palm olein-olive oil blend. $J \mathrm{Am}$ Oil Chem Soc 87: 255-262. Available from https://doi.org/ 0.1007/s11746-009-1495-z.

Nakatani N, Tachibana Y, Kikuzaki H. 2001. Establishment of a model substrate oil for antioxidant activity assessment by oil stability index method. JAm Oil Chem Soc 78: 19-23.

Nestel P, Clifton P, Noakes M. 1994. Effects of increasing dietary palmoleic acid compared with palmitic and oleic acids on plasma lipids of hypercholesterolemic men. J Lipid Res 35: 656-662.

Poudyal H, Panchal S, Waanders J, Ward L, Brown L. 2012. Lipid redistribution by $\alpha$-linolenic acid-rich chia seed inhibits stearoylCoA desaturase-1 and induces cardiac and hepatic protection in diet-induced obese rats. $J$ Nutr Biochem 23: 153-162. Available from https://doi.org/10.1016/j.jnutbio.2010.11.011.

Ramadan MF, Amer MMA, Awad A. 2008. Coriander (Coriandrum sativum $\mathrm{L}$.) seed oil improves plasma lipid profile in rats fed diet containing cholesterol. Eur Food Res Technol 227: 1173-1182. Available from https://doi.org/10.1007/s00217-008-0833-y.

Ramadan MF, Mörsel JT. 2003. Oil cactus pear (Opuntia ficus-indica L.). Food Chem 82: 339-345. Available from https://doi.org/ $10.1016 / \mathrm{S} 0308-8146(02) 00550-2$.
Ramadan MF, Mörsel JT. 2004. Oxidative stability of black cumin (Nigella sativa L.), coriander (Coriandrum sativum L.) and niger (Guizotia abyssinica Cass.) upon stripping. Eur J Lipid Sci Technol 106: 35-43. Available from https://doi.org/10.1002/ ejlt.200300895.

Ramírez-Moreno E, Cariño-Cortés R, Cruz-Cansino ND, et al. 2017. Antioxidant and antimicrobial properties of cactus pear (Opuntia) seed oils. J Food Qual: e3075907. Available from https://doi.org/ 10.1155/2017/3075907.

Réblová Z. 2006. The effect of temperature on the antioxidant activity of tocopherols. Eur J Lipid Sci Technol 108: 858-863. Available from https://doi.org/10.1002/ejlt.200600091.

Sabliov CM, Fronczek C, Astete CE, Khachaturyan M, Khachatryan L, Leonardi C. 2009. Effects of temperature and UV light on degradation of a-tocopherol in free and dissolved form. $J$ Am Oil Chem Soc 86: 895-902. Available from https://doi.org/10.1007/ s11746-009-1411-6.

Salama MA, Owon MA, Osman MF, Esmail AI, Matthäus B. 2018. Characterization of Egyptian Moringa oleifera lipids (whole seeds and kernels). J Food Dairy Sci Mansoura Univ 9(12): 371376. Available from https://doi.org/10.21608/jfds.2018.36087.

Salama MA, Owon MA, Osman MF, Esmail AI, Matthäus B. 2020. Effect of germination and roasting on oil profile of Moringa oleifera and Moringa peregrina seeds. J Food Meas Charact 14: 2220-2229. Available from https://doi.org/10.1007/s11694-020-00469-2.

Shahidi F, Zhong Y. 2010. Lipid oxidation and improving the oxidative stability. Chem Soc Rev 39: 4067-4079. Available from https://doi.org/10.1039/B922183M.

Shin TS, Godber JS, Martin DE, Wells JH. 1997. Hydrolytic stability and changes in E vitamers and oryzanol of extruded rice bran during storage. J Food Sci 62: 704-708. Available from https:// doi.org/10.1111/j.1365-2621.1997.tb15440.x.

Steel RG, Torrie JH. 1980. Principles and procedures of statistics. London: McGraw Hill.

Taoufik F, Zine S, El Hadek M, et al. 2015. Oil content and main constituents of cactus seed oils Opuntia ficus indica of different origin in Morocco. Mediterr J Nutr Metab 8(2): 85-92. Available from https://doi.org/10.3233/MNM-150036.

Torres M, Lioret C, Sosa M, Maestri D. 2006. Composition and oxidative stability of soybean oil in mixtures with jojoba oil. Eur J Lipid Sci Technol 108: 513-520. Available from https://doi.org/ 10.1002/ejlt.200500282.

Torres M, Martínez ML, Pierantozzi P, Albanese M, Nasjleti A, Maestri D. 2011. Contribution of compositional parameters to the oxidative stability of olive and walnut oil blends. J Am Oil Chem Soc 88(6): 755-762. Available from https://doi.org/0.1007/ s11746-010-1735-2.

Yanishlieva NV, Marinova EM. 1996. Antioxidative effectiveness of some natural antioxidants in sunflower oil. Z Lebensm Unters Forsch 203: 220-223.

Verleyen T, Verhe R, Huyghebaert A, Dewettinck K, De Greyt W. 2001. Identification of alpha-tocopherol oxidation products in triolein at elevated temperatures. J Agric Food Chem 49: 15081511. Available from https://doi.org/10.1021/jf001142f.

Wanger K, Kamal-Eldin A, Elmadfa I. 2004. Gamma-tocopherol An underestimated vitamin? Ann Nutr Metab 48: 169-188. Available from https://doi.org/10.1159/000079555.

Cite this article as: Salama MA, El Harkaoui S, Nounah I, Sakr H, Abdin M, Owon M, Osman M, Ibrahim A, Charrouf Z, Matthäus B. 2020. Oxidative stability of Opuntia ficus-indica seeds oil blending with Moringa oleifera seeds oil. OCL 27: 53. 